\title{
Dynamic Economic Dispatch Pada Sistem Kelistrikan Microgrid Dengan Penambahan Media Penyimpan Energi Menggunakan Quadratic Programming
}

\author{
Fakhruddin Wirakusuma, Heri Suryoatmojo, dan Rony Seto Wibowo \\ Jurusan Teknik Elektro, Fakultas Teknologi Industri, Institut Teknologi Sepuluh Nopember (ITS) \\ Jl. Arief Rahman Hakim, Surabaya 60111 Indonesia

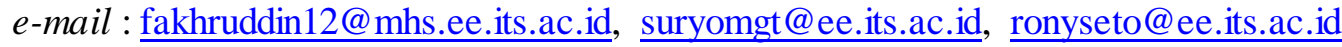

\begin{abstract}
Abstrak - Kebutuhan daya listrik saat ini meningkat pesat seiring dengan perkembangan teknologi. Peningkatan kebutuhan daya listrik ini bertolak belakang dengan menipisnya ketersediaan sumber energy minyak dan batu bara. Permasalahan ini berdampak pada ketahanan listrik nasional. Untuk memenuhi kebutuhan daya listrik yang besar dengan cakupan wilayah yang luas diperlukan pembangkit tersebar berskala kecil. Pembangkit tersebar ini diupayakan bersumber pada energi terbarukan untuk meminimalkan pemakaian dari sumber energy minyak dan batu bara lalu dihubungkan ke Micro Grid serta digunakan baterai sebagai power balance. Oleh karena banyaknya pembangkit tersebar dan penggunaan baterai maka penting untuk menentukan besarnya pembangkitan daya listrik yang optimal dari masing-masing pembangkit serta penggunaan baterai berdasarkan kapasitas yang optimal sehingga kebutuhan daya listrik dapat dipenuhi dengan biaya yang minimal tiap waktunya. Optimisasi ini dikenal dengan istilah Dynamic Economic Dispatch. Optimisasi ini sudah banyak dilakukan dilakukan dengan berbagai macam metode Artificial Intelligence. Pada penelitian ini, metode Artificial Intellegence yang diaplikasikan yakni Quadratic Programming. Metode ini diterapkan pada software MATLAB.
\end{abstract}

Kata Kunci- Microgrid, Dynamic Economic Dispatch, Quadratic Programming, Battery, Energy Storage

\section{PENDAHULUAN}

$\mathrm{T}$ IENAGA listrik merupakan salah satu kebutuhan yang sangat penting dalam kehidupan manusia. Permintaan daya listrik yang terus bertambah menyebabkan daya listrik yang harus disuplai oleh pembangkit menjadi sangat besar. Sumber energi yang dapat diperbaharui serta ekonomis adalah faktor penentu perkembangan industri yang bisa meningkatkan standar hidup masyarakat. Sejak revolusi industri, kebutuhan energi listrik meningkat tajam [1]. Sebagai bentuk yang baik dalam membangkitkan daya yang besar dengan cakupan wilayah yang luas, sistem pembangkitan tersebar menjadi penting untuk memenuhi permintaan beban, menaikkan keandalan, dan sebagainya [2,3]. Economic dispatch (ED) merupakan hal penting dalam kontrol dan operasi pada sistem tenaga [4]. Fungsi utama dari ED adalah untuk menjadwalkan pembangkitan dari setiap pembangkit yang beroperasi untuk dapat memenuhi kebutuhan beban pada biaya pembangkitan paling minimal [5].

Selain dari biaya operasi, faktor yang sangat penting untuk dianalisis yaitu penggunaan baterai sebagai power balance. Penggunaan baterai pada kondisi tertentu dapat menyediakan daya listrik pada kondisi real time, namun konstrain keterbatasan energy yang disimpan dalam battery juga dapat membatasi performa dalam penyediaan daya listrik pada titik tertentu [6]. Maka dari itu, penting untuk menentukan kapasitas battery yang optimal sehingga dapat disambung dalam sistem Micro Grid.

Dynamic Economic Dispatch merupakan suatu metode optimisasi untuk menentukan pembangkitan paling optimum dengan biaya pembangkitan yang minimum dengan memperhitungkan pembangkitan tiap waktu yang continuous dari setiap unit pembangkit. DED merupakan pengembangan dari Economic Dispatch konvensional oleh karena itu diperlukan pendekatan yang sederhana dan efektif untuk mencari solusi global yaitu menggunakan Quadratic Programming [7].

\section{DASAR TEORI}

\section{A. Sistem Kelistrikan Micro Grid}

Sistem kelistrikan Micro Grid merupakan sistem kecil dengan berbagai teknologi diantaranya pembangkit thermal seperti diesel generator, micro turbine dan fuell cell serta pembangkit berbasis renewable energy seperti photovoltaic, wind turbine, dan baterai. Pembangkit dibuat tersebar berskala kecil serta dibangkitkan dekat dengan beban untuk meningkatkan keandalan sistem serta meminimalkan rugi-rugi jaringan. Sistem yang digunakan dalam penelitian ini adalah sistem dengan tipe operasi islanded. Dengan tipe operasi ini, daya listrik dari jala-jala PLN tidak digunakan sehingga mendekati kondisi nyata pulau-pulau terluar di Indonesia yang tidak dilewati jala-jala PLN. Beberapa sumber energi listrik yang dimodelkan dalam sistem micro grid ini yaitu wind turbine, photovoltaic, fuel cell, micro turbine, diesel generator dan baterai. 


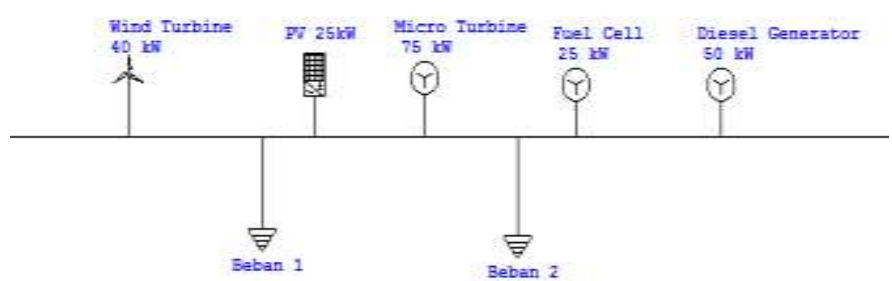

Gambar 1. Tipe microgrid mode operasi islanded

\section{B. Dynamic Economic Dispatch}

Dynamic economic dispatch adalah pembagian daya yang harus dibangkitkan oleh generator dalam suatu sistem tenaga listrik sehingga dapat memenuhi kebutuhan beban dengan biaya minimum. Besar beban pada suatu sistem tenaga selalu berubah setiap periode waktu tertentu, oleh karena itu untuk mensuplai beban secara ekonomis pada tiap periode waktu- $t$ untuk setiap $h$-unit generator, perhitungan optimisasi dynamic economic dispatch dilakukan.

Pada sistem micro grid, dynamic economic dispatch dilakukan untuk menentukan besar daya pembangkitan optimum dari pembangkit thermal (fuel cell, micro turbine, dan diesel generator) serta penggunaan daya dari battery pada tiap periode waktu- $t$ agar tercapai biaya pembangkitan yang minimal. Penentuan daya pembangkitan pada setiap generator hanya boleh bervariasi pada batas-batas (constraints) tertentu. Cost function dari $h$-unit generator dalam periode waktu- $t$ dimodelkan dengan persamaan:

$$
C F_{h t}=a_{h t} P_{h t}{ }^{2}+b_{h t} P_{h t}+c_{h t}
$$

Dimana :

$C F_{h t} \quad$ : total biaya operasi generator thermal $(€ / \mathrm{h})$

$a, b$, dan $c$ : koefisien biaya generator thermal

$P_{h t} \quad$ : daya yang dibangkitkan pembangkit $h$ pada periode waktu $\mathrm{t}(\mathrm{kW})$

Hubungan daya yang dibangkitkan oleh pembangkit tidak linier terhadap biaya pembangkitan, kombinasi daya output yang dibangkitkan oleh tiap $h$-unit generator pada periode waktu- $t$ pada sistem pembangkit harus bisa memenuhi kebutuhan daya dari suatu sistem tenaga listrik (eauality constraint) dan memenuhi batas minimum dan batas maksimum dari daya yang dibangkitkan oleh generator (inequality constraint). Karena permasalahannya cukup rumit maka penyelesaian permasalahan bisa dilakukan dengan metode iterasi, parameter parameter yang telah dijelaskan dapat ditulis dalam persamaan:

$C F_{h t}=\sum_{t=1}^{T}\left(\sum_{h=1}^{n}\left(a_{h t} P_{h t}^{2}+b_{h t} P_{h t}+c_{h t}\right)\right)$

Dimana :

$C F_{h t} \quad$ : total biaya operasi generator thermal $(€ / \mathrm{h})$

$a, b$, dan $c$ : koefisien biaya generator thermal

$P_{h t} \quad$ : daya yang dibangkitkan pembangkit $h$ pada periode waktu $\mathrm{t}(\mathrm{kW})$
$P_{F C} \min \leq P_{F C} \leq P_{F C} \max$

$P_{M T} \min \leq P_{M T} \leq P_{M T} \max$

$P_{D G} \min \leq P_{D G} \leq P_{D G} \max$

$P_{\text {charge }} \min \leq P_{\text {batt }} \leq P_{\text {charge }} \max$

Dimana :

$P_{F C} \min \quad$ : daya operasi minimum dari fuel cell

$P_{F C} \max \quad$ : daya operasi maksimum dari fuel cell

$P_{M T} \min \quad:$ daya operasi minimum dari micro turbine

$P_{M T} \max \quad$ : daya operasi maksimum dari micro turbine

$P_{D G} \min \quad$ : daya operasi minimum dari diesel generator

$P_{D G} \max \quad$ : daya operasi maksimum dari diesel generator

$P_{\text {charge }} \min$ : daya operasi minimum dari battery

$P_{\text {charge }} \max$ : daya operasi maksimum dari battery

$P_{F C} \min =5 \mathrm{~kW}$

$P_{F C} \max =25 \mathrm{~kW}$

$P_{M T} \min =5 \mathrm{~kW}$

$P_{M T} \max \quad=75 \mathrm{~kW}$

$P_{D G} \min \quad=2 \mathrm{~kW}$

$P_{D G} \max =6 \mathrm{~kW}$

$P_{\text {charge }} \min =0 \mathrm{~kW}$

$P_{\text {charge }} \max =30 \mathrm{~kW}$

Dari seluruh pembangkit yang ada pada sistem, terdapat tiga pembangkit yang membutuhkan bahan bakar untuk dapat beroperasi. Pembangkit tersebut adalah fuel cell, micro turbine, dan diesel generator. Fuel cell dan micro turbine menggunakan gas alam sebagai bahan bakar dan diesel generator menggunakan bahan bakar solar. Besar biaya pada pembangkit thermal selain dipengaruhi oleh karakteristik dari mesin juga dipengaruhi oleh biaya bahan bakar, oleh karena itu ketiga pembangkit tersebut memiliki karakteristik yang berbeda.

Selain ketiga pembangkit berbahan bakar tersebut, pembangkit yang pembangkitan dayanya memerlukan biaya adalah battery, yang dihitung berdasarkan biaya pembelian dan perawatan battery yang telah dijelaskan pada persamaan battery. Adapun fungsi dari total biaya operasi pembangkit tersebut adalah sebagai berikut :

$C F(P)=C F\left(P_{F C}\right)+C F\left(P_{M T}\right)+C F\left(P_{D G}\right)+C F\left(P_{b a t t}\right)$

Dimana :

$C F(P)$ : total biaya operasi pembangkit yang memiliki biaya pembangkitan dalam $€ / \mathrm{h}$

$C F\left(P_{F C}\right)$ : total biaya operasi fuel cell dalam $€ / \mathrm{h}$

$C F\left(P_{M T}\right)$ : total biaya operasi micro turbine dalam $€ / \mathrm{h}$

$C F\left(P_{D G}\right)$ : total biaya operasi diesel generator dalam $€ / \mathrm{h}$

$C F\left(P_{\text {batt }}\right)$ : total biaya operasi battery dalam $€ / \mathrm{h}$

\section{Quadratic Programming pada Sistem Micro Grid}

Model linier programming merupakan sebuah model yang sangat handal untuk digunakan dalam analisa berbagai permasalahan sains, industry, engineering, dan bisnis. Namun, model ini memiliki keterbatasan karena tidak semua permasalahan berbentuk linier. Selain itu, model linier hanya 
memberikan hasil terbaik pada permasalahan dengan orde pertama. Model yang berada satu tingkat diatas model ini adalah quadratic programming. Quadratic programming menyelesaikan permasalahan non linier dan memodelkannya ke dalam sebuah fungsi objektif. Quadratic programming adalah salah satu metode optimisasi yang secara khusus digunakan untuk mengoptimalkan (meminimalkan atau memaksimalkan) masalah masalah fungsi kuadrat dari beberapa variabel yang bergantung pada batasan linier pada variabel-variabel yang ditentukan.

Permasalahan optimisasi linier yang dibatasi dengan fungsi tujuan kuadrat disebut quadratic programming. Karena dapat diaplikasikan pada berbagai bidang [8], quadratic programming sering dipandang sebagai suatu disiplin ilmu tersendiri. Selain itu, quadratic programming juga membentuk dasar dari beberapa algoritma pemrograman umum non linier lain.

Quadratic programming dapat dimodelkan dalam sebuah persamaan berikut:

$F(x)=f+c^{T} x+\frac{1}{2} x^{T} H x$

Sesuai dengan constraint sistem linier

$l b \leq A x \leq u b$

$x \min \leq x \leq x \max$

Dimana :

$\mathrm{f}=$ konstanta skalar

$\mathrm{c}=$ konstanta matriks n-vektor

$\mathrm{H}=$ matriks $n \times n$

$\mathrm{A}=$ matriks $m \times n$

$u b, l b=$ konstanta m-vektor

$x=\mathrm{n}$-vektor yang tidak diketahui

\section{PEMODELAN SISTEM}

Permodelan yang dilakukan pada penelitian sistem microgrid ini adalah sistem distribusi microgrid tipe radial yang berasal dari referensi. Sistem disuplai oleh diesel generator $50 \mathrm{kw}$, fuel cell $25 \mathrm{kw}$, micro turbine $75 \mathrm{kw}$, wind turbine $40 \mathrm{kw}$, dan photovoltaic $25 \mathrm{kw}$, serta ditopang oleh battery 300kwh.

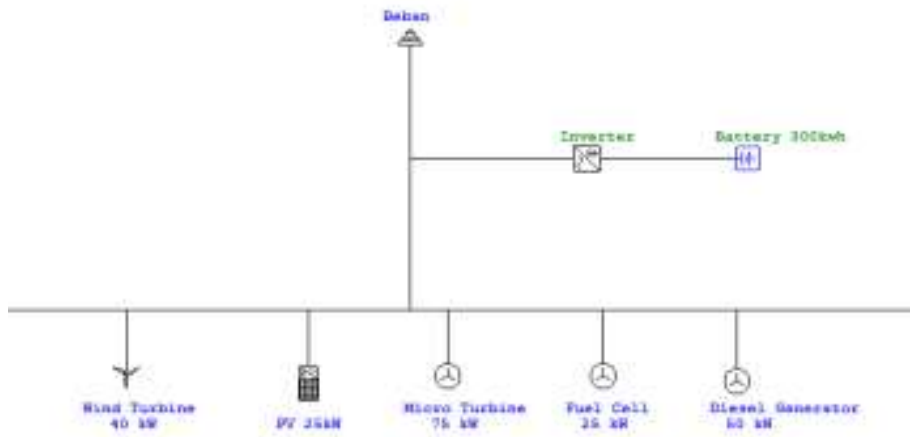

Gambar 2. Sistem kelistrikan micro grid

\section{A. Photovoltaic}

Karakteristik photovoltaic yang ada sudah di tes dalam suatu kondisi standar $\left(1000 \mathrm{~W} / \mathrm{m}^{2}\right.$ dan $\left.25{ }^{\circ} \mathrm{C}\right)$ untuk menghasilkan daya yang sesuai dengan rating photovoltaic tersebut, apabila kita ingin menggunakan photovoltaic tersebut maka kita harus memperhitungkan pengaruh radiasi dan suhu pada karakteristik photovoltaic yang dimodelkan. Daya keluaran dari modul photovoltaic dapat dihitung dengan persamaan:

$P_{p v}=\mathrm{M}\left\{P_{s t c} \frac{G_{T N E}}{G_{S T C}}(1+k(T c-T r))\right\}$

Dimana :

$P_{P V}$ : daya keluaran dari modul saat radiasi $G_{I N G}$ dalam W

$P_{S T C}:$ daya maksimum modul saat STC dalam W

$G_{I N G}:$ radiasi aktual dalam $\mathrm{W} / \mathrm{m}^{2}$

$G_{S T C}$ : radiasi saat STC $\left(1000 \mathrm{~W} / \mathrm{m}^{2}\right)$

$\mathrm{M}$ : jumlah modul photovoltaic

$K \quad$ : koefisien suhu untuk daya modul dalam $\% /{ }^{\circ} \mathrm{C}$

$T_{C} \quad$ : suhu sel dalam ${ }^{\circ} \mathrm{C}$

$T_{R} \quad$ : referensi suhu $\left(25^{\circ} \mathrm{C}\right)$

Dalam penelitian ini digunakan modul photovoltaic SOLAREX MSX-83 [9]. Karena dalam penelitian ini photovoltaic yang akan dimodelkan memiliki rating $25 \mathrm{~kW}$, maka digunakan paramater sebagai berikut :

Jumlah Modul = 302

Daya maksimum saat STC $\left(P_{S T C}\right) \quad=25 \mathrm{~kW}$

Tegangan saat daya maksimum $=17.1 \mathrm{~V}$

Arus saat daya maksimum $\quad=4.85 \mathrm{~A}$

Arus short circuit saat STC $=5.27 \mathrm{~A}$

Tegangan short circuit saat STC $=21.2 \mathrm{~V}$

Koefisien suhu untuk daya $(\mathrm{k})=-0.5$

\section{B. Wind Turbine}

Karena dalam penelitian ini dibutuhkan wind turbine dengan rating $40 \mathrm{~kW}$, maka digunakan 2 buah turbin angin ReDriven $20 \mathrm{~kW}$. Kurva daya dari wind turbine ini adalah sebagai berikut:

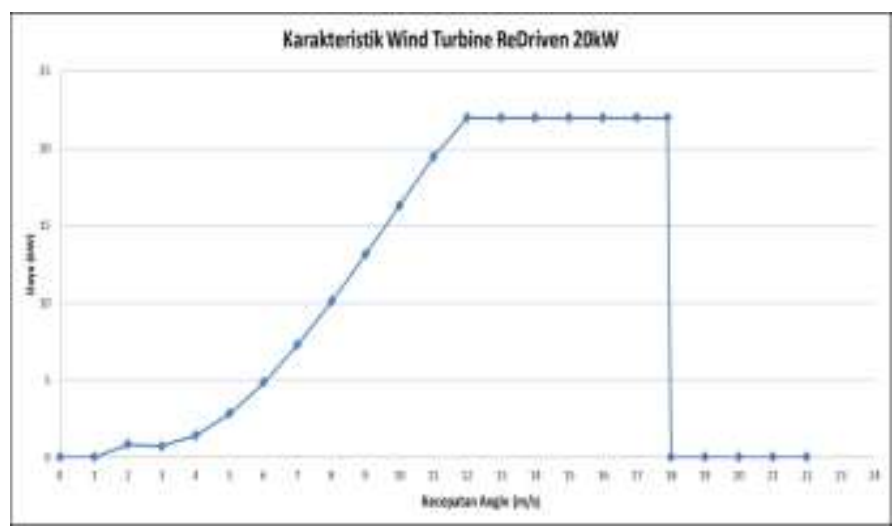

Gambar 3. Kurva daya model dari ReDriven 20kW

Dari model kurva daya tersebut dapat diperoleh persamaan sebagai berikut :

$P_{W T}=0, V_{a c}<V_{c i}$

$P_{W T}=a V_{a c}^{3}+b V_{a c}^{2}+c V_{a c}+d V_{c i} \leq V_{a c} \leq V_{r}$

$P_{W T, r}=0, V_{r} \leq V_{a c}$ dan $V_{c o}<V_{a c}$ 
Dimana :

$P_{W T}$ : daya keluaran dari turbin angin dalam $\mathrm{kW}$

$P_{c o}$ : daya saat cut-out dalam $\mathrm{kW}$

$V_{r} \quad$ : rating kecepatan angin dalam $\mathrm{m} / \mathrm{s}$

$V_{a c}:$ kecepatan angin aktual dalam $\mathrm{m} / \mathrm{s}$

$V_{c i}:$ kecepatan $c u t$-in dalam $\mathrm{m} / \mathrm{s}$

$V_{c o}:$ kecepatan cut-out dalam $\mathrm{m} / \mathrm{s}$

Berdasarkan kurva wind turbine diatas maka kita dapat memeroleh data terkait performansi dari wind turbine, persamaan matematis yang bisa kita peroleh berdasarkan kurva diatas adalah parameter sebagai berikut:
$a=-0.0196$
$b=0.5874$
$c=-2.6814$
$d=4.0076$
$P_{c o}=0$
$V_{c i}=2$
$V_{c o}=18$
$V_{r}=11$

\section{Fuel Cell.}

Biaya operasi dari fuel cell dapat dinyatakan sebagai fungsi daya keluaran dan dapat dimodelkan dengan poninomial kuadrat. Biaya operasi untuk fuel cell adalah sebagai berikut:

$C F\left(P_{F C}\right)=a P_{F C}^{2}+b P_{F C}+c$

Dimana :

$C F\left(P_{F C}\right) \quad$ : total biaya operasi fuel cell $(€ / \mathrm{h})$

$a, b$, dan $c$ : koefisien generator

$P_{F C} \quad:$ keluaran daya darifuel cell $(\mathrm{kW})$

Dalam penelitian ini digunakan sebuah fuel cell $25 \mathrm{~kW}$ yang mempunyai fungsi biaya bahan bakar yang diambil dari referensi [10].

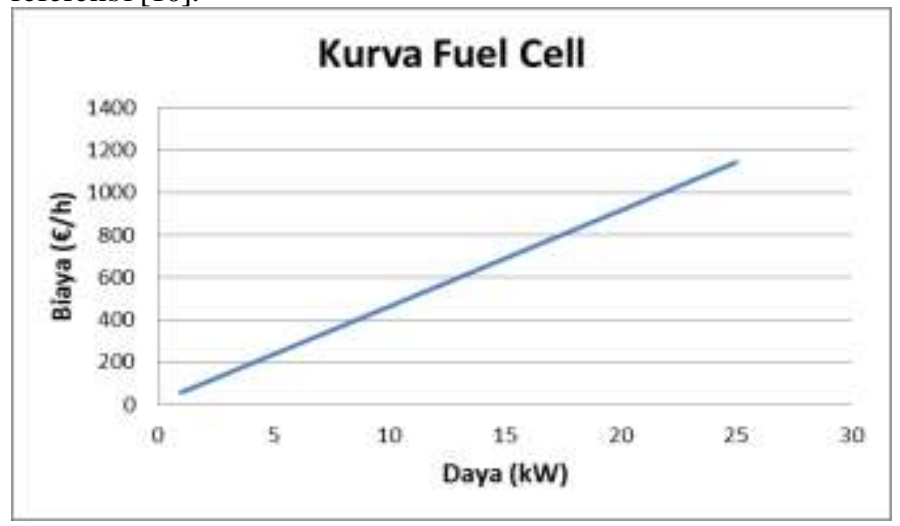

Gambar 4. Kurva biaya bahan bakar Fuel cell

Dari kurva diatas didapatkan parameter sebagai berikut:

$a=0.01$

$b=45$

$c=12$

\section{Micro Turbine}

Biaya operasi dari micro turbine dapat dinyatakan sebagai fungsi daya keluaran dan dapat dimodelkan dengan polinomial kuadrat. Adapun fungsi biaya operasi untuk micro turbine adalah sebagai berikut:

$C F\left(P_{M T}\right)=a P_{M T}^{2}+b P_{M T}+c$

Dimana :

$C F\left(P_{M T}\right) \quad$ : total biaya operasi micro turbine $(€ / \mathrm{h})$

$a, b$, dan $c$ : koefisien generator

$P_{M T} \quad$ : keluaran daya dari micro turbine $(\mathrm{kW})$

Dalam penelitian ini digunakan sebuah micro turbine $75 \mathrm{~kW}$ yang mempunyai fungsi biaya bahan bakar yang diambil dari referensi [10]. Adapun kurva biaya bahan bakarnya adalah sebagai berikut:

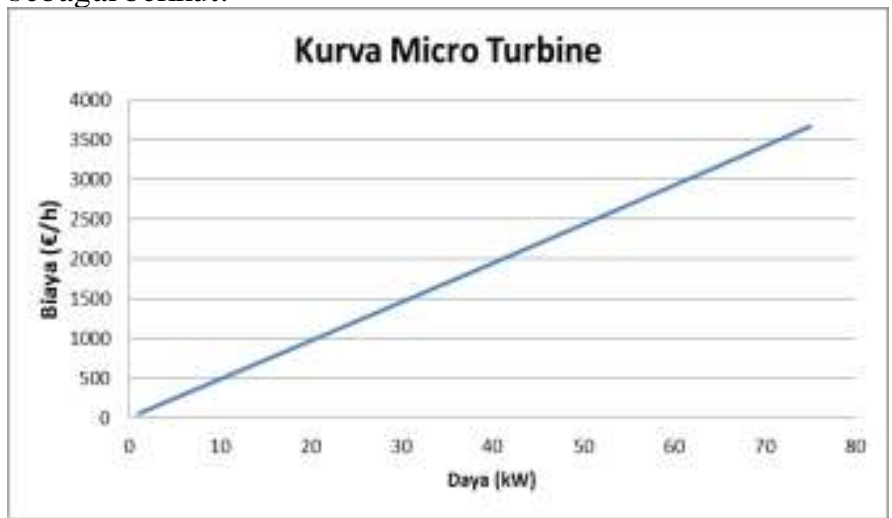

Gambar 5. Kurva biaya bahan bakar Micro Turbine

Dari kurva diatas didapatkan parameter sebagai berikut:

$a=0.01$

$b=48$

$c=12$

\section{E. Diesel Generator}

Biaya operasi untuk diesel generator dimodelkan dalam fungsi kuadrat sebagai berikut :

$C F\left(P_{D G}\right)=\left(a P_{D G}^{2}+b P_{D G}+c\right)$

Dimana :

$C F\left(P_{D G}\right) \quad$ : total biaya operasi diesel generator $(€ / \mathrm{h})$

$a, b$, dan $c:$ koefisien generator

$P_{D G} \quad$ : keluaran daya dari diesel generator $(\mathrm{kW})$

Dalam penelitian ini digunakan sebuah diesel generator 50 kW yang mempunyai fungsi biaya bahan bakar yang diambil dari referensi [10]. 


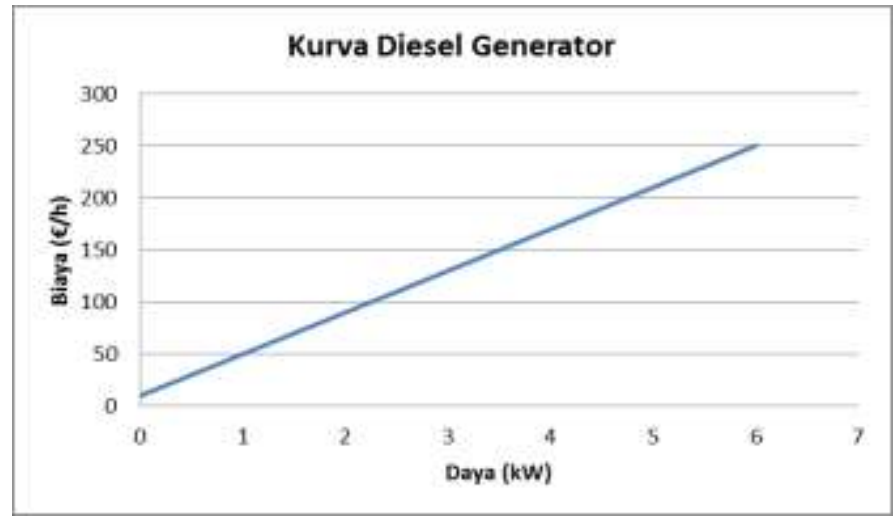

Gambar 6. Kurva biaya bahan bakar Diesel Generator

Dari kurva diatas didapatkan parameter sebagai berikut:

$a=0.01$

$b=40$

$c=10$

\section{F. Battery}

Dalam penelitian ini digunakan permodelan battery yang diambil dari referensi sebagai berikut [11]:

$C F\left(P_{\text {batt }}\right)=0.003831 P_{\text {batt }}(€ / \mathrm{h})$

$P_{\text {minbatt }} \quad: 60 \mathrm{kWh}$

$P_{\text {maxbatt }} \quad: 300 \mathrm{kWh}$

$P_{\text {charge }} \min : 0 \mathrm{~kW}$

$P_{\text {charge }} \max : 30 \mathrm{~kW}$

Dimana :

$C F\left(P_{\text {batt }}\right) \quad$ : total biaya operasi battery $(€ / \mathrm{h})$

$P_{\text {batt }} \quad:$ keluaran daya dari battery $(\mathrm{kW})$

$P_{\text {minbatt }} \quad:$ kapasitas daya minimal dari battery $(\mathrm{kWh})$

$P_{\text {maxbatt }} \quad:$ kapasitas daya maksimal dari battery $(\mathrm{kWh})$

$P_{\text {charge }} \min \quad$ : daya operasi minimum dari battery $(\mathrm{kW})$

$P_{\text {charge }} \max \quad$ : daya operasi maksimum dari battery $(\mathrm{kW})$

\section{STUDI KASUS}

Akan ditampilkan hasil perhitungan berupa tabel-tabel yang meliputi pembangkitan optimal, biaya total, arah aliran daya battery serta kapasitas battery pada berbagai kondisi radiasi matahari dan kecepatan angin. Hasil dari simulasi ini akan memperlihatkan perbandingan dari aplikasi metode terhadap beberapa studi kasus. Terdapat 4 studi kasus yang mempresentasikan variasi kemungkinan yang terhadi di sistem micro grid. Kondisi beban selama 24 periode waktu (1 hari) dalam penelitian ini diasumsikan sama untuk setiap studi kasusnya. Dalam studi kasus ini akan diketahui pengaruh penggunaan battery serta pengaruh radiasi matahari dan kecepatan angin terhadap biaya total, dalam penelitian ini biaya pemeliharaan dan pembelian / pengadaan komponen diabaikan.

Tabel 1.

Daftar Studi Kasus dan Deskripsi

\begin{tabular}{ccc}
\hline \multicolumn{3}{c}{ Daftar Studi Kasus dan Deskripsi } \\
\hline \multirow{2}{*}{ Studi Kasus } & Radiasi Matahari dan Kecepatan & Battery \\
& Angin & Tidak terkoneksi \\
1 & Konstan & Terkoneksi \\
2 & Konstan & Tidak terkoneksi \\
\hline
\end{tabular}

\begin{tabular}{llc}
\hline \hline 4 & Bervariasi & Terkoneksi \\
\hline
\end{tabular}

Inputan untuk studi kasus 1 dan 2 ada pada pada tabel 2 kemudian inputan studi kasus 3 dan 4 ada pada tabel 3

Tabel 2.

Data Masukan Studi Kasus 1 dan Studi Kasus 2

\begin{tabular}{ccccc}
\hline \hline Pukul & $\begin{array}{c}\text { Total } \\
\text { Beban } \\
(\mathrm{kW})\end{array}$ & $\begin{array}{c}\text { Kecepatan } \\
\text { Angin }(\mathrm{m} / \mathrm{s})\end{array}$ & $\begin{array}{c}\text { Radiasi } \\
\text { Matahari } \\
(\mathrm{W} / \mathrm{m} 2)\end{array}$ & $\begin{array}{c}\text { Suhu } \\
\text { (celcius) }\end{array}$ \\
\hline 1 & 25 & 10 & 1000 & 30 \\
2 & 30 & 10 & 1000 & 30 \\
3 & 35 & 10 & 1000 & 30 \\
4 & 40 & 10 & 1000 & 30 \\
5 & 53 & 10 & 1000 & 30 \\
6 & 57 & 10 & 1000 & 30 \\
7 & 73 & 10 & 1000 & 30 \\
8 & 84 & 10 & 1000 & 30 \\
9 & 95 & 10 & 1000 & 30 \\
10 & 134 & 10 & 1000 & 30 \\
11 & 141 & 10 & 1000 & 30 \\
12 & 137 & 10 & 1000 & 30 \\
13 & 189 & 10 & 1000 & 30 \\
14 & 175 & 10 & 1000 & 30 \\
15 & 166 & 10 & 1000 & 30 \\
16 & 97 & 10 & 1000 & 30 \\
17 & 82 & 10 & 1000 & 30 \\
18 & 106 & 10 & 1000 & 30 \\
19 & 105 & 10 & 1000 & 30 \\
20 & 117 & 10 & 1000 & 30 \\
21 & 120 & 10 & 1000 & 30 \\
22 & 93 & 10 & 1000 & 30 \\
23 & 20 & 10 & 1000 & 30 \\
24 & 17 & 10 & 1000 & 30 \\
\hline \hline
\end{tabular}

Tabel 3.

Data Masukan Studi Kasus 3 dan Studi Kasus 4

\begin{tabular}{ccccc}
\hline \hline Pukul & $\begin{array}{c}\text { Total } \\
\text { Beban } \\
(\mathrm{kW})\end{array}$ & $\begin{array}{c}\text { Kecepatan } \\
\text { Angin }(\mathrm{m} / \mathrm{s})\end{array}$ & $\begin{array}{c}\text { Radiasi } \\
\text { Matahari } \\
(\mathrm{W} / \mathrm{m} 2)\end{array}$ & $\begin{array}{c}\text { Suhu } \\
\text { (celcius) }\end{array}$ \\
\hline 1 & 25 & 5 & 0 & 25 \\
2 & 30 & 5 & 0 & 25 \\
3 & 35 & 5 & 0 & 25 \\
4 & 40 & 5 & 0 & 25 \\
5 & 53 & 5 & 50 & 25 \\
6 & 57 & 5 & 200 & 30 \\
7 & 73 & 5 & 200 & 30 \\
8 & 84 & 10 & 500 & 30 \\
9 & 95 & 10 & 500 & 30 \\
10 & 134 & 10 & 1000 & 30 \\
11 & 141 & 10 & 1000 & 30 \\
12 & 137 & 10 & 1000 & 30 \\
13 & 189 & 10 & 1000 & 30 \\
14 & 175 & 10 & 1000 & 30 \\
15 & 166 & 10 & 1000 & 30 \\
16 & 97 & 5 & 500 & 30 \\
17 & 82 & 5 & 200 & 30 \\
18 & 106 & 5 & 200 & 30 \\
19 & 105 & 5 & 50 & 30 \\
20 & 117 & 10 & 0 & 30 \\
21 & 120 & 10 & 0 & 25 \\
22 & 93 & 10 & 0 & 25 \\
23 & 20 & 10 & 0 & 25 \\
24 & 17 & 10 & 0 & 25 \\
\hline \hline
\end{tabular}




\section{ANALISA STUDI KASUS}

Pada bab IV telah dilakukan studi kasus terhadap dynamic economic dispatch menggunakan energy storage berdasarkan metode quadratic programming. Studi kasus 1 menggunakan kondisi cuaca konstan dan tidak terhubung battery, studi kasus 2 menggunakan kondisi cuaca konstan serta terhubung battery. Sementara studi kasus 3 menggunakan kondisi cuaca bervariasi dan tidak terhubung battery, dan studi kasus 4 menggunakan kondisi cuaca bervariasi dan terhubung battery. Dengan menggunakan level beban yang sama untuk tiap periode waktu, berikut adalah total biaya pembangkitan tiap studi kasus pada tabel 4.

Tabel 4.

Perbandingan Biaya Total Pembangkitan

\begin{tabular}{ccc}
\hline \hline No & Studi Kasus & $\begin{array}{c}\text { Biaya Total Pembangkitan } \\
(€)\end{array}$ \\
\hline 1 & Studi Kasus 1 & 43563.4442 \\
2 & Studi Kasus 2 & 32699.4988 \\
3 & Studi Kasus 3 & 66334.1250 \\
4 & Studi Kasus 4 & 60401.4239 \\
\hline \hline
\end{tabular}

Dari semua studi kasus yang telah dilakukan, didapatkan daya optimum tiap pembangkit, level daya battery tiap periode waktu serta biaya pembangkitan total. Karena pada tiap studi kasus digunakan level beban yang sama untuk tiap periode waktu (24 jam), dapat terlihat bahwa:

- Total daya yang dibangkitkan jumlahnya selalu sama dengan level beban yang diminta karena dianggap sistem tanpa rugi-rugi.

- Pembangkitan renewable yang diprioritaskan terlebih dahulu ialah photovoltaic setelah itu wind turbine karena daya yang dihasilkan photovoltaic lebih stabil.

- Pengoperasian battery menjadi prioritas utama dibandingkan dengan pembangkit berbahan bakar. Setelah penggunaan battery, pengoperasian diesel generator mendapat prioritas pengoperasian karena memiliki biaya operasi lebih murah dibandingkan dengan pembangkit berbahan bakar yang lainnya. Sedangkan micro turbine mendapatkan prioritas terakhir dalam pengoperasiannya karena memiliki biaya operasi yang paling mahal.

\section{KESIMPULAN}

Berdasarkan hasil simulasi dan analisis dynamic economic dispatch menggunakan metode quadratic programming yang diaplikasikan dalam sistem dengan variasi pembangkit pada sistem kelistrikan microgrid terkoneksi battery dapat diambil kesimpulan sebagai berikut

Quadratic programming dapat digunakan untuk menentukan pembebanan tiap pembangkit dalam sistem micro grid sehingga didapatkan biaya yang paling minimal.

Penggunaan media penyimpan energi mampu mengurangi total biaya keseluruhan. Pada kondisi radiasi matahari dan kecepatan angin yang konstan yaitu pada studi kasus 1 dan studi kasus 2 didapatkan total biaya $€ 43563.4442$ dan $€$ 32699.4988. Lalu pada kondisi radiasi matahari dan kecepatan angin yang bervariasi yaitu pada studi kasus 3 dan studi kasus 4 didapatkan total biaya $€ 66334.1250$ dan $€ 60401.4239$.

Kondisi cuaca mempengaruhi total daya pembangkitan karena pembangkit renewable sangat tergantung oleh cuaca (radiasi, suhu, dan kecepatan angin) dan mempengaruhi total biaya pembangkitan.

\section{DAFT AR PUST AKA}

[1] Imam Robandi, "Modern Power System Control”, Penerbit ANDI, Yogyakarta, 2009.

[2] WANG Jiang-hai, TAI Neng-ling, SONG Kai, "Penetration Level Permission of for DG in Distributed Network Considering Relay Protection," Proceedings of the CSEE, 30 (2010), No. 22, 37-43.

[3] YU Kun, CAO Yijia, CHEN Xingying, "Dynamic Probability Power Flow of District Grid Containing Distributed Generation," Proceedings of the CSEE, 31 (2011), No. 1, 20-25.

[4] Naoto Yorino, Hafiz Mohd Habibuddin, Zoka Yoshifumi, Sasaki Yutaka, Ohnishi Yuji,"Dynamic Economic Dispatch with Generator's Feasible Operation Region", Power and Energy Engineering Conference (APPEEC), 2010 Asia-Pacific, 10.1109/APPEEC.2010.5448180, 2010.

[5] D. W. Ross, S. Kim, "Dynamic Economic Dispatch of Generation", IEEE Trans. on Power Apparatus and Systems, vol. PAS-99, no. 6, pp. 2060-2068, Nov. 1980.

[6] Mahmodi Mishel, Pourya Shamsi,and Fahimi Babak "Economic Dispatch of a Hybrid Microgrid With Distributed Energy Storage" IEEE Transactions on Smart Grid vol. 6, no. 6, Nov. 2015.

[7] Ray Daniel Zimmerman, Carlos Edmundo Murillo-Sanchez, and Robert John Thomas "MATPOWER: Steady-State Operations, Planning, and Analysis Tools for Power System Research and Education" IEEE Transactions on Power System vol. 26, no. 1, Nov. 2011.pg 12-19.

[8] Hariadi Viktor, Soeliman Rully, "Application of Adaptive Brrier Function for Solving Nonlinear Optimization Problem: Quadratic Programming Problem (as Case Study)”, IE (1) Journal EL vol.86 (2005).

[9] Mohamed Faisal A, Koivo Heikki., "System modelling and online optimal management of MicroGrid using Mesh Adaptive Direct Search", International Journal of Electrical Power \& Energy Systems., Vol. 32,no 5 . 2010, pp. 398-407.

[10] Xiaoping Liu, Ming Ding, Jianghong Han, Pingping Han and Yali Peng, "Dynamic Economic Dispatch for Microgrids Including Battery Energy Storage", 2nd IEEE International Symposium on Power Electronics for Distributed Generation Systems, 2010.

[11] Deckmyn Christof, L. Vandoorn Tine, Moradzades Mohammad and Vandevelde Lieven, "Multi-objective optimization for environomic scheduling in microgrids", IEEE 2014. 